\title{
Analysis of Science Process Skills for Senior High School Students in Banjarmasin
}

\author{
Arief Ertha Kusuma ${ }^{1, *}$ Rusmansyah $^{2}$ \\ ${ }^{1}$ Universitas Borneo Tarakan \\ ${ }^{2}$ Lambung Mangkurat University \\ *Corresponding author. Email: artha13qren@gmail.com
}

\begin{abstract}
Science teachers who know the level of students 'science process skills will easily design good learning in order to improve students' knowledge and skills. This study aims to describe the level of science process skills of high school students in Banjarmasin City. The science process skill level of students was diagnosed by giving multiple choice questions to 466 students from five State Senior High Schools in Banjarmasin. Data analysis is presented as a percentage and visualized in graphical form for each indicator of science process skills and discussed with the theory and findings of previous research. The results of the research data analysis showed that the science process skills of the students in the study sample were generally LOW. A total of 65.07 percent of students were in the LOW category, 26.11 percent of students were in the MEDIUM category, and 8.83 percent of students were in the HIGH category. There are five indicators of science process skills that are categorized as low, namely indicators making graphs and interpreting data 41 percent, indicators designing experiments 47 percent, indicators making operational definitions 53 percent, indicators identifying and controlling variables 54 percent and one indicator that is classified as moderate, namely stating hypotheses with a percentage 64 percent. The low percentage of the five indicators of process skills can be used as an indication that science learning (Physics, Chemistry, and Biology) is still not optimal in training students' science process skills. These results show that in science learning there is still a need for the development and application of innovative learning models so as to train students' science process skills optimally.
\end{abstract}

Key words: Science Process Skills, Profiles, Students, Percentages.

\section{INTRODUCTION}

Science process skills are very important for every student because they are the basic assets of using scientific methods in developing science and acquiring new knowledge or developing existing knowledge. Science process skills need to be developed in learning as a way to ensure that students master the concepts being taught properly [1]. Likewise [2] states "... Science process skills are not only important for those pursuing careers in science, but also for the most part in millennial jobs involving these skills ...". The importance of mastering science process skills is recognized by several studies and research in recent times, including [3] states that science process skills are tools used by students to investigate the world around them and build knowledge concepts, so it is important for teachers to train students to have understanding and developing these skills in the lessons taught. [4] suggests that students with high scores for basic process skills have a tendency to obtain higher scores for integrated science process skills. Therefore, the teacher needs to determine the level of science process skills of students before learning or laboratory activities so that they can plan lessons that can improve students' science process skills. [5] states teachers have a great responsibility to develop students' science process skills. Therefore, higher education institutions that educate teachers must pass prospective teachers as fully equipped. Teachers can create activities and use effective learning materials to help students develop the skills of the science process.

Another study shows that teachers' mastery of the concept of science process skills by teachers is still low, this was revealed by the study of [1] who stated that preservice teachers had a poorer conceptual understanding of science process skills than did performance in science process skills. Poor definitions and explanations provided by the research sample regarding a concept reveal that they do not have complete conceptual knowledge of the scientific process, and have difficulty 
defining and explaining processes such as inferring, communicating, formulating hypotheses, experimenting, formulating models, interpreting data, predicting, identify variables and graphs. Therefore, science teachers must be proficient in science process skills at many levels, and must have the knowledge and understanding to teach science process skills. [6] state policies for science education in secondary schools should reinforce the need to build and equip science laboratories in all secondary schools to encourage student involvement in practice-related activities. When students engage in experiments during chemistry lessons, students hone process skills and acquire scientific skills that have an impact on overall achievement in chemistry. [7] state that the government should pay more attention to steps to improve students' science process skills. Training for science teachers, especially those oriented to the development of science process skills and assessment of science process skills, needs to be carried out. The mastery of good science process skills by science teachers both conceptually and practically will make it easier for the teacher to train and make students master science process skills well. Science process skills are the ability of students to apply scientific methods in understanding, developing and discovering knowledge. Science process skills are required to acquire, develop and apply scientific concepts, principles, laws, and theories. [8] stated that science process skills can be divided into two groups, namely 1) basic science process skills (simple) and 2) integrated science process skills (complex). Basic science process skills (simple), consisting of 1) Observing, 2) Concluding, 3) Measuring, 4) Communicating, and 5) Classifying, 6) Predicting. Meanwhile, integrated (complex) science process skills include identifying and defining variables, collecting and changing data, creating data tables and graphs, describing relationships between variables, interpreting data, manipulating material, recording data, formulating hypotheses, designing investigations, making conclusions and generalizations.

Science learning taught by science teachers should require students to understand the concept thoroughly, deeply and broadly and practice skills that can be applied in real life. The learning process that is carried out must make students engage and participate well in learning, understand and master the concepts being learned. Good mastery of concepts will improve application and process science skills. On the contrary, good science process skills support mastery of science concepts and their application. This research was conducted to obtain the profile of science process skills of high school students in Banjarmasin city as an effort and the first step in developing learning that can train science process skills in learning so that teachers have consideration and alternative materials to prepare lesson plans that develop and improve students' science process skills. The main question that will be answered in this study is how is the profile of the science process skills of high school students in Banjarmasin?

\section{METHODOLOGY}

The study was conducted at high schools in Banjarmasin in August - September 2018 using the pen and paper test technique. The number of students in this study was 466 students at five State Senior High Schools in Banjarmasin who were determined randomly. Each student school is determined by three classes, namely class X, XI, and XII. Data were collected using an integrated science process skills test instrument consisting of 30 multiple choice questions. The question text used was adapted from the instrument used by Kazeni Mungandi Monde Monica, University of Pretoria, South Africa in 2005. The instrument used in this study will measure 5 indicators of process skills, namely identifying and controlling variables, stating hypotheses, making operational definitions, making graphs and interpreting data, and designing experiments.

The data obtained in the form of a score for each question that was answered correctly was given a score of one and the wrong answer was given a score of zero. To determine the percentage of students' science process skills, it is calculated using a formula

$P=\frac{S P}{S M} X 100 \%$

With

P: The percentage of students' science process skills

SP: the total score for each question.

SM: the maximum score for each question.

The categorization of students' science process skill level was carried out by referring to table 1

Table 1 categories of percentage ranges of students' science process skills

\begin{tabular}{ccc}
\hline No & Range Of Percentage & Category \\
\hline 1 & $76 \%-100 \%$ & High \\
\hline 2 & $60 \%-75 \%$ & Medium \\
\hline 3 & $<60 \%$ & Low
\end{tabular}

Adapted From [9]

The categorization and percentage obtained are then used to present descriptive analysis to describe in general and thoroughly related to the skills profile of the science process of high school students in Banjarmasin.

\section{RESULT OF RESEARCH}

The results of students' science process skills tests at five State Senior High Schools in Banjarmasin which are grouped into the High, Medium, and Low categories can be seen in diagram 1 below. 


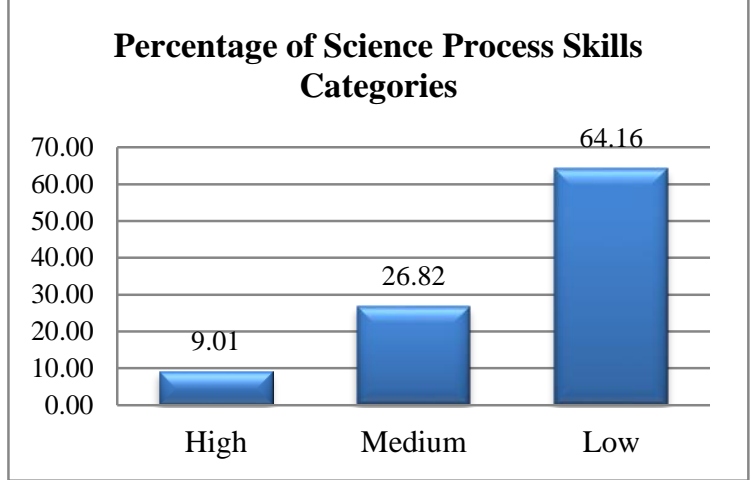

\section{Diagram 1 Percentage of students' Science Process} Skills

Diagram 1 above shows that in general, it can be said that the science process skills of the students used as the research sample are still LOW with the percentage distribution of the science process skills categories of Banjarmasin high school students in detail can be seen in table 2 below.

Table 2 Distribution of the Percentage of Students' Science Process Skills Category

\begin{tabular}{|c|c|c|c|c|c|}
\hline \multirow{2}{*}{$\begin{array}{l}\text { School } \\
\text { Name }\end{array}$} & \multirow[t]{2}{*}{ Class } & \multirow{2}{*}{$\begin{array}{l}\text { Number } \\
\text { of } \\
\text { Students }\end{array}$} & \multicolumn{3}{|c|}{$\begin{array}{c}\text { Percentage of Category } \\
(\%)\end{array}$} \\
\hline & & & High & Medium & Low \\
\hline \multirow{3}{*}{$\begin{array}{l}\text { SMAN } \\
2\end{array}$} & $\mathrm{X}$ & 33 & 0.00 & 30.00 & 70.00 \\
\hline & $\mathrm{XI}$ & 30 & 0.00 & 13.33 & 86.67 \\
\hline & XII & 30 & 13.33 & 66.67 & 20.00 \\
\hline \multirow{3}{*}{$\begin{array}{c}\text { SMAN } \\
3\end{array}$} & $\mathrm{X}$ & 35 & 5.71 & 45.71 & 48.57 \\
\hline & XI & 36 & 0.00 & 25.00 & 75.00 \\
\hline & XII & 34 & 2.94 & 55.88 & 41.18 \\
\hline \multirow{3}{*}{$\begin{array}{c}\text { SMAN } \\
7\end{array}$} & $\mathrm{X}$ & 36 & 5.56 & 41.67 & 52.78 \\
\hline & XI & 32 & 90.63 & 6.25 & 3.13 \\
\hline & XII & 28 & 14.29 & 64.29 & 21.43 \\
\hline \multirow{3}{*}{$\begin{array}{l}\text { SMAN } \\
10\end{array}$} & $\mathrm{X}$ & 38 & 0.00 & 0.00 & 100.0 \\
\hline & XI & 28 & 0.00 & 0.00 & 100.0 \\
\hline & XII & 31 & 0.00 & 19.35 & 80.65 \\
\hline \multirow{3}{*}{$\begin{array}{l}\text { SMAN } \\
12\end{array}$} & $\mathrm{X}$ & 34 & 0.00 & 5.88 & 94.12 \\
\hline & XI & 18 & 0.00 & 0.00 & 100.0 \\
\hline & XII & 23 & 0.00 & 17.39 & 82.61 \\
\hline Total & 15 & 466 & & & \\
\hline
\end{tabular}

Of the five sample schools in the study, there were three schools where most of the students had a science process skill level in the LOW and MEDIUM categories. The other two sample schools had a small proportion of students having science process skills that were in the HIGH category.

Based on the grade level, the percentage of the science process skill level of the 466 sample students is shown in table 3

Table 3 Percentage of Science Process Skills by Grade Level

\begin{tabular}{ccc}
\hline \multirow{2}{*}{ Class } & \multicolumn{2}{c}{ Percentage (\%) } \\
\cline { 2 - 3 } & High Medium Low \\
\hline
\end{tabular}

\begin{tabular}{lrrr}
\hline X & 2.82 & 28.87 & 68.31 \\
\hline XI & 24.17 & 12.50 & 63.33 \\
\hline XII & 6.16 & 45.89 & 47.95 \\
\hline
\end{tabular}

Table 2 above shows that the percentage of the LOW category is greater than the MEDIUM and HIGH categories for each grade level.

Then the researcher described the percentage of correct answers on each indicator of science process skills in table 4

Table 4 Percentage of correct answers for each indicator

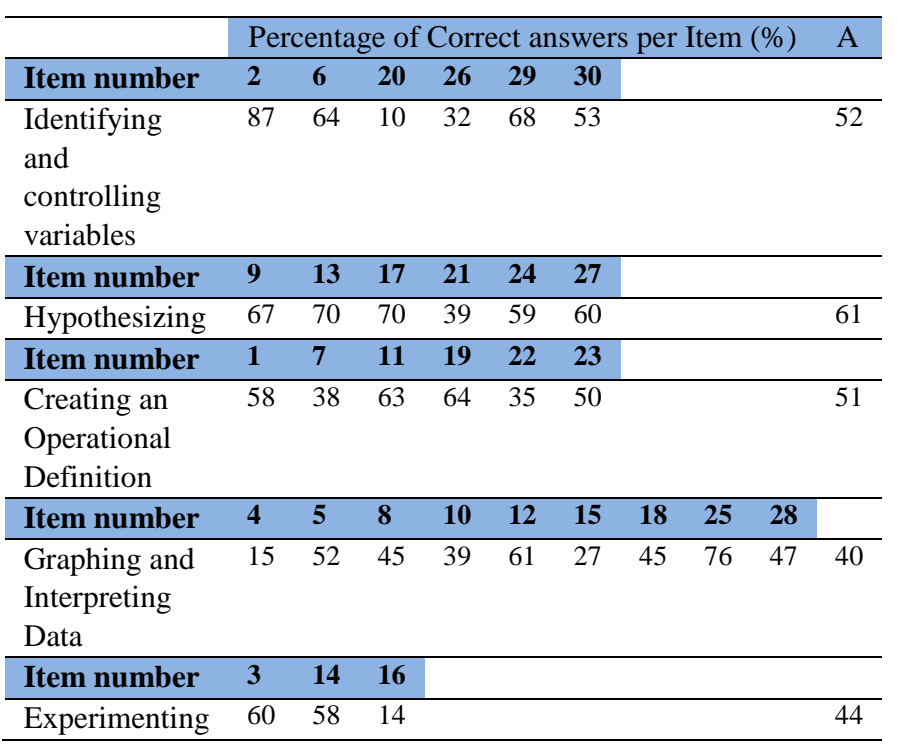

A: Average of Percentage

Table 4 above shows the indicators charting and interpreting data; and designing experiments to have the smallest percentage than other indicators.

Researchers also compared the percentage of each indicator of process skills based on grade X, XI, XII levels and obtained data as shown in Table 5

Table 5 Comparison of the percentage of correct answers per indicator for each class

\begin{tabular}{ccccc}
\hline \multirow{2}{*}{$\begin{array}{c}\text { Science Process } \\
\text { Skills Indicators }\end{array}$} & \multicolumn{4}{c}{ Percentage Each Class (\%) } \\
\cline { 2 - 5 } & $\mathrm{X}$ & $\mathrm{XI}$ & $\mathrm{XI}$ & $\mathrm{A}$ \\
\hline $\begin{array}{c}\text { Identifying and } \\
\text { controlling } \\
\text { variables }\end{array}$ & 52 & 52 & 58 & 54 \\
\hline Hypothesizing & 61 & 65 & 67 & 64 \\
\hline $\begin{array}{c}\text { Creating an } \\
\text { Operational } \\
\text { Definition }\end{array}$ & 52 & 52 & 56 & 53 \\
\hline $\begin{array}{c}\text { Graphing and } \\
\text { Interpreting Data }\end{array}$ & 36 & 41 & 45 & 41 \\
\hline Experimenting & 47 & 45 & 48 & 47 \\
\hline
\end{tabular}

Table 5 shows that the class $\mathrm{X}$ student group is the group with the lowest percentage of correct answers compared to class XI and XII for indicators of making graphs and designing experiments. 


\section{DISCUSSION}

Diagram 1 shows that as many as $64.14 \%$ or 299 of all students who were the research sample belong to the LOW category of science process skills. Similar results were stated by [10-12] who obtained the achievement of science process skills from the research sample were still low. Some of the factors that influence the low achievement of science process skills include almost $85 \%$ of teachers still using teacher-centered learning methods, the learning process is only the transfer of knowledge from teacher to student, does not develop student learning methods, does not develop appropriate ways of implementing the learning process, and the lack of students' experiences in investigative activities. Involving students in practicum activities can improve mastery of science process skills and the ability to understand scientific concepts [6].

Science learning should give students the opportunity to sharpen, clarify or ask scientifically oriented questions, plan and carry out experiments to collect data about questions, formulate explanations from evidence to answer questions, link explanations with scientific knowledge, and communicate and justify questions. The large percentage of science process skills in the low category shows that in the city of Banjarmasin there are still many high school students who have not been trained and have mastered the knowledge and skills to solve problems related to scientific work.

Tables 2 and 3 showed that the largest percentage of the low category is in class $\mathrm{X}$ and XI, this shows that students in class $\mathrm{X}$ and $\mathrm{XI}$ are not familiar and trained to solve science process skills questions. Class X students are just getting to know or remember learning activities related to science process skills. Meanwhile, class XI students seem to be less trained and accustomed to solving questions that are science process skills. The factor of not being used to and being trained, just getting to know or remembering science process skills makes students in class $\mathrm{X}$ and $\mathrm{XI}$ less able to master the concept and apply it in solving science process skills questions, as stated by $[10,11]$. The percentage of low category students in class XII is smaller than the percentage of class $\mathrm{X}$ and XI, this is because class XII students are more often and accustomed to receiving assignments related to science process skills from grades $\mathrm{X}$ and XI. This is in line with the findings of [5] who state that differences between grade levels have a significant effect on the potential use of science process skills in addition to the type of school, scores and the order of selection for high school entry. However, the research data shows that the low category percentage of class XII students reaches $47.95 \%$. This indicates that class XII students are still not trained in applying knowledge and skills related to science process skills.
Table 4 shows the indicators of making graphs and interpreting data into indicators of science process skills with the lowest average percentage, namely 40 percent. This shows that students still have weaknesses when faced with problems related to graphics, both questions that require interpreting the qualitative meaning of a graph and questions that ask students to make or determine graphs based on the data given in the questions. [12] is also argue similarly that the possible reason for the low ability of students to graph and interpret data was the lack of opportunities students had to practice data interpretation skills and draw conclusions. This happens because most teachers often skip this step because it is considered time consuming in learning. The difficulties experienced by the high school students of Banjarmasin who were the samples of this study were evident from the many students' wrong answers when answering the indicator questions in making graphs and interpreting data. [13] is argued that students' difficulties in interpreting the graph were divided into two. First, the difficulty of relating the graph to physics concepts such as matching between graphs, narrating a graph, or interpreting the area under a curve. The second is the difficulty of connecting real events graphically such as difficulty understanding graphical representations of continuous motion, constant acceleration and negative velocity.

Table 5 shows the indicators of making graphs and interpreting data are the indicators with the lowest percentage of the five indicators of science process skills tested with an average percentage of $41 \%$. In the indicators of making graphs and interpreting data students are asked to answer 9 items that aim to (1) is remember the description of the investigation and obtain the results / data, identify the graph that describes the data. And (2) recalling the graph or data table from the investigation, identifying the relationships between the variables. The percentage of correct answers was $36 \%$ of class X students, $41 \%$ of class XI students and $45 \%$ of class XII students. Grade X students have the lowest percentage because they are new to acquaintances, are less accustomed to, and are less accustomed to receiving assignments and using science process skills than students of class XI and XII. Class level differences have a significant effect on the potential use of science process skills as suggested by [5].

Another indicator that has a low percentage is designing experiments. In measuring this indicator students are asked to answer 3 items. Students are required to be able to determine hypotheses, choose a suitable design for the investigation to test the chosen design. On this indicator, the percentage of students' correct answers is only $48 \%$ for class XII students, $45 \%$ for class XI students and $47 \%$ for class X students with an average correct answer of $47 \%$ and is classified into the low category. Learning that is oriented towards material completion is conceptually suspected to be the 
cause of the low percentage of this indicator. This data is coherent with the findings of [12] who states that the low percentage of correct answers on the indicators of designing the experiment is that in science learning there is only a model (no experiment) that describes concepts and theories, so that students may not be able to understand the concepts and topics well and cannot relate the concepts obtained to the appropriate experiment. [6] is also stated that the objectives of students being involved in science practicum activities include increasing mastery of science process skills and increasing the ability to understand concepts.

[14] states that process skills are becoming increasingly recognized as an important goal of education in secondary schools because it helps students build knowledge about scientific phenomena and, at the same time, helps them to think, think critically, and solve problems. Therefore, science learning at the high school level should be able to make students to master the concept of science well as a means to train students' science process skills so that students can understand the concepts and skills of the science process as a whole.

\section{CONCLUSION}

Based on data analysis and discussion, it was concluded that the science process skills of students of SMAN Banjarmasin city were still in the LOW category. This is indicated by the percentage of $64.16 \%$ of students in the low category. The indicator of science process skills that has the lowest percentage is making graphs and interpreting data, namely $40 \%$, and designing experiments 44\%. Science learning (Physics, Chemistry, and Biology) needs to emphasize aspects and activities that train and develop science process skills for students, especially in indicators of making graphs and interpreting data and designing experiments. Therefore, it is necessary to develop learning models and teaching materials oriented to train and develop students' science process skills and the results are applied in learning science (Physics, Chemistry, and Biology) in high school.

\section{AUTHORS' CONTRIBUTIONS}

Arief Ertha Kusuma contributed to data collection, data analysis, and writing the article draft. Rusmansyah contributed to article review, proofreading, and editing.

\section{ACKNOWLEDGMENTS}

Thank you for the implementation of this research addressed to the Head of the Education and Culture Office of South Kalimantan Province, the Head of SMAN 2 Banjarmasin, the Head of SMAN 3 Banjarmasin, the Head of SMAN 7 Banjarmasin, the
Head of SMAN 10 Banjarmasin, and the Head of SMAN 12 Banjarmasin.

\section{REFERENCES}

[1] Chabalengula V M, Mumba F and Mbewe S 2012 How Pre-service Teachers' Understand and Perform Science Process Skills Eurasia J. Math. Sci. Technol. Educ. 8 167-76

[2] Keil C, Haney J and Zoffel J 2009 Improvements in Student Achievement and Science Process Skills Using Environmental Health Science Problem-Based Learning Curricula 13 1-18

[3] Singh N 2015 Challenges Faced In The Implementation Of Science Process Skills: A Study Of Primary Year Two Pre-service Teachers' Practicum Experience 1 2705-13

[4] Irwanto, Rohaeti E and Prodjosantoso A C 2018 Undergraduate Students' Science Process Skills In Terms Of Some Variables: A Perspective From Indonesia J. Balt. Sci. Educ. 17 761-4

[5] Gürses A, Çetinkaya S, Doğar Ç and Şahin E 2015 Determination of Levels of Use of Basic Process Skills of High School Students Procedia Soc. Behav. Sci. 191 644-50

[6] Abungu H E, Okere M I O and Wachanga S W 2014 The Effect of Science Process Skills Teaching Approach on Secondary School Students' Achievement in Chemistry in Nyando District, Kenya J. Educ. Soc. Res. 4 359-71

[7] Sukarno, Permanasari A and Hamidah I 2013 The Profile of Science Process Skill (SPS) Student at Secondary High School (Case Study in Jambi) 15

[8] Monica K M M 2005 Development And Validation Of A Test Of Integrated Science Process Skills For The Further Education And Training Learners (South Africa: University Of Pretoria)

[9] Arikunto S 2013 Prosedur Penelitian: Suatu Pendekatan Praktik (Jakarta: Rineka Cipta)

[10] Bulent A 2015 The Investigation Of Science Process Skills Of Science Teachers In Terms Of Some Variables Educ. Res. Rev. 10 582-94

[11] Handayani A S, Kirana T, Rahayu Y S and Jayanti P 2018 Implementation Of Guided Discovery Learning To Improve Student Science Process Skills Of Junior High School Proceedings of the 2nd International Conference on Education Innovation (ICEI 2018) Proceedings of the 2nd 
International Conference on Education Innovation (ICEI 2018) (Surbaya, Indonesia: Atlantis Press)

[12] Lati W, Supasorn S and Promarak V 2012 Enhancement Of Learning Achievement And Integrated Science Process Skills Using Science Inquiry Learning Activities of Chemical Reaction Rates Procedia - Soc. Behav. Sci. 46 4471-5

[13] McDermott L C, Rosenquist M L and van Zee E H 1987 Student Difficulties In Connecting Graphs And Physics: Examples From Kinematics Am. J. Phys. 55 503-13

[14] Germann P J 1994 Testing A Model Of Science Process Skills Acquisition: An Interaction With Parents' Education, Preferred Language, Gender, Science Attitude, Cognitive Development, Academic Ability, And Biology Knowledge $J$. Res. Sci. Teach. 31 749-83 